\title{
LEGAL EDUCATION REFORM AND THE GOOD LAWYER
}

\author{
Alice WOOLLEY*
}

The critics agree: law schools do it wrong. Stuck in early twentieth century practices that emphasize instruction in legal doctrine in large lecture halls, law schools fail to provide their students with the skills necessary to be practicing lawyers and to be marketable to prospective employers. They fail to instill in their students the "professional identity" necessary to achieve ethical legal practice. This article sounds a cautionary note with respect to those proposals for reform that reject the traditional emphasis on doctrinal teaching. In particular, and in contrast to the critics who view doctrinal learning as inconsistent with, or unrelated to, the creation of ethical lawyers, this article suggests that the emphasis on law in law school serves an essential function in creating ethical legal practice.
La critique s'entend pour dire que les écoles de droit ne s'y prennent pas correctement. Ancrées dans les pratiques du vingtième siècle soulignant l'instruction d'une doctrine juridique dans de grandes salles de conférences, les écoles de droit ne fournissent pas aux étudiants les compétences nécessaires pour devenir des praticiens et être compétitifs auprès d'employeurs éventuels. Ils n'insufflent pas «l'identité professionnelle» nécessaire aux étudiants dans l'exercice d'une pratique juridique éthique. Cet article se veut un avertissement relatif aux projets de réforme rejetant l'importance de l'enseignement traditionnel. Surtout et contrairement aux critiques qui estiment que cette méthode d'apprentissage n'est pas conforme ou non reliée à la formation d'avocats éthiques, cet article laisse entendre que l'importance que les écoles de droit accordent au droit est essentielle à une pratique juridique éthique.

\section{TABLE OF CONTENTS}

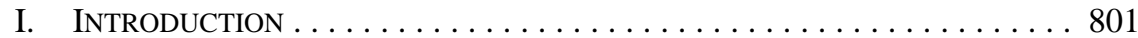

II. Too Much LaW: The Problem With Legal Education . . . . . . . . . 804

III. LAW AND THE LAWYER . . . . . . . . . . . . . . . . . . . . . . . . . . . . . 806

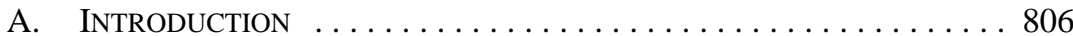

B. DEFINING LAWYER'S PROFESSIONAL

DUties IN PRACTICE . . . . . . . . . . . . . . . . . . . . . . 807

C. THE NORMATIVE FOUNDATIONS

OF THE LAWYER'S ROLE . . . . . . . . . . . . . . . . . . . . . 809

D. LAWYERS ACTING BADLY $\ldots \ldots \ldots \ldots \ldots \ldots \ldots \ldots \ldots \ldots \ldots$

IV. CURRICULUM REFORM AND THE ETHICAL LAWYER . . . . . . . . . . . . . . . 814

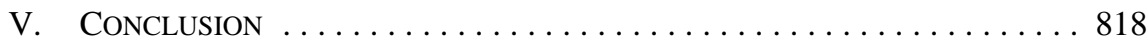

\section{INTRODUCTION}

The critics agree: law schools do it wrong. Stuck in early twentieth century practices that emphasize instruction in legal doctrine in large lecture halls, law schools fail to provide their students with the skills necessary to be practicing lawyers and to be marketable to 
prospective employers. ${ }^{1}$ They fail to instill in their students the "professional identity" necessary to achieve ethical legal practice. ${ }^{2}$

Such criticism of the adequacy of legal education has been a persistent feature of professional and academic thought for the last fifty years, ${ }^{3}$ but has gained more urgency and intensity with the economic collapse of 2008, the impact of that collapse on the market for legal services, and consequently, on the market for legal education. Critics argue that observable and fundamental shifts in how legal services are provided mean that the kind of legal services market for which law schools have prepared their graduates has gone for good. ${ }^{4}$ The new legal services market requires very different things from law school graduates than that for which their schools prepare them. ${ }^{5}$

This article does not reject the impetus for legal education reform. Many of the articles on legal education reform include creative ideas for how to engage students and to ensure that they learn. ${ }^{6}$ My personal experience from seven years of legal practice naturally draws me to the position that law schools could do more to prepare students for its demands. Here

The consensus on the flaws of legal education was nicely summarized by Rebecca Sandefur and Jeffrey Selbin: "Law schools teach students to think like lawyers but not to act like them. That is, while law schools prepare students to reason analytically (the cognitive dimension), they neither prepare students adequately for the practice of law (the skills dimension), nor instill in them sufficiently a sense of professional responsibility and public obligation (the civic dimension).” Rebecca Sandefur \& Jeffrey Selbin, "The Clinic Effect” (2009) 16:1 Clinical L Rev 57 at 58 [emphasis in original]. They note that there is "considerable consensus on the limits of the current model" (ibid at 59).

2 The idea of "professional identity" comes from the 2007 Carnegie Report. William M Sullivan et al, Educating Lawyers: Preparation for the Profession of Law (San Francisco: Jossey-Bass, 2007) at 3-4, 28 [The Carnegie Report]. For a strong summary of the report see Mark Yates, "The Carnegie Effect: Elevating Practical Training Over Liberal Education in Curricular Reform” (2011) 17 The Journal of the Legal Writing Institute 233.

See e.g. The Carnegie Report, ibid; Paul Carrington, “Appendix A: Carrington Report” in Herbert L Packer \& Thomas Ehrlich, New Directions in Legal Education (Berkeley: Carnegie Commission on Higher Education, 1972) 93; American Bar Association Section of Legal Education and Admissions to the Bar, Legal Education and Professional Development - An Educational Continuum: Report of The Task Force on Law Schools and The Profession: Narrowing the Gap (Chicago: American Bar Association, 1992) [The MacCrate Report]; Working Group on Lawyer Conduct and Professionalism, A National Action Plan on Lawyer Conduct and Professionalism (Conference of Chief Justices, 1999); Roy Stuckey et al, Best Practices for Legal Education, 1st ed (Clinical Legal Education Association, 2007).

$4 \quad$ See e.g. James E Moliterno, “The Future of Legal Education Reform” (2013) 40:2 Pepp L Rev 423 at 429. See also Thomas D Morgan, “The Changing Face of Legal Education: Its Impact on What It Means to Be a Lawyer” (2012) 45:4 Akron L Rev 811.

$5 \quad$ See e.g. William D Henderson, “A Blueprint for Change” (2013) 40:2 Pepp L Rev 461. In particular, a significant thread of recent scholarship on legal education discusses teaching innovations adopted by particular schools or professors. These articles are not discussed further here but are worth noting for schools considering innovative change. See generally Andrea M Seielstad, "Enhancing the Teaching of Lawyering Skills and Perspectives Through Virtual World Engagement” (2012) 7 U Mass L Rev 40; Nantiya Ruan, "Experiential Learning in the First-Year Curriculum: The Public-Interest Partnership" (2011) 8 Legal Communication \& Rhetoric: JALWD 191; Laurie Morin \& Susan Waysdorf "The Service-Learning Model in the Law School Curriculum" (2011-2012) 56:2 NYL Sch L Rev 561; Ira Steven Nathenson, "Navigating the Uncharted Waters of Teaching Law with Online Simulations" (2012) 38:2 Ohio NUL Rev 535; Nancy M Maurer \& Liz Ryan Cole, "Design, Teach and Manage: Ensuring Educational Integrity in Field Placement Courses” (2012) 19:1 Clinical L Rev 115; Deborah Maranville et al, "Re-vision Quest: A Law School Guide to Designing Experiential Courses Involving Real Lawyering” (2011-2012) 56:2 NYL Sch L Rev 517; Kathy Douglas \& Belinda Johnson, "Legal Education and E-Learning: Online Fishbowl Role-Play as a Learning and Teaching Strategy in Legal Skills Development” (2010) 17:1 eLaw Journal 28; Carrie Hempel, “Writing on a Blank Slate: Creating a Blueprint for Experiential Learning at the University of California, Irvine School of Law" (2011) 1:1 UC Irvine L Rev 146; Hope Eckert, “Teach This Class!” (2011) 3:1 Faulkner L Rev 95; Gregory M Duhl, “Equipping Our Lawyers: Mitchell's Outcomes-Based Approach to Legal Education” (2012) 38:3 Wm Mitchell L Rev 906; Peggy Cooper David \& James Webb, "Learning from Dramatized Outcomes" (2012) 38:3 Wm Mitchell L Rev 1146; Charlotte S Alexander, "Learning to Be Lawyers: Professional Identity and the Law School Curriculum” (2011) 70:2 Md L Rev 465. 
though I sound a cautionary note with respect to those proposals for reform that reject the traditional emphasis on doctrinal teaching. In particular, and in contrast to the critics who view doctrinal learning as inconsistent with, or unrelated to, the creation of ethical lawyers, this article suggests that the emphasis on law in law school serves an essential function in creating ethical legal practice. ${ }^{7}$

In every normatively grounded explanation for what lawyers ought to do in discharging their professional obligations, the demands and constraints of law play a fundamental role. Whether understood through the norms of political or moral philosophy, the lawyer's role requires that a lawyer's representation of clients be constrained by legality. At no point do client demands in and of themselves warrant violation of legal rules and obligations, and morality apart from law plays at most a secondary role in defining what lawyers ought to do in any particular situation. ${ }^{8}$ Further, when considered as a matter of legal practice - through observing the actual duties and obligations with which lawyers must comply, and the sorts of errors made by lawyers when they act improperly - the centrality of law to defining the lawyer's professional responsibilities is clear. The law frames lawyers' duties and obligations - not just the law directly governing lawyers, but the totality of the legal system within which their clients seek to realize their goals and pursue their interests. Lawyers act improperly when they misapply or misinterpret the law to pursue their clients' goals, or when they violate the law on their clients' behalf.

Law schools that emphasize doctrinal teaching and learning endorse the normative framework and knowledge most important to the creation of ethical practitioners. Through the consistent emphasis on the need for students to identify the law and to apply it to factual scenarios, and by assessing whether students have mastered the ability to understand and apply the law, doctrinal courses reinforce the centrality of the law to legal work. Doctrinal courses may not result in students retaining much specific information about the subjects taught. They may not directly teach law students about how to resolve the dilemmas of ethical practice, such as confidentiality or conflicts of interest. ${ }^{9}$ They may not "teach morality as a central element of legal education," ${ }^{10}$ or inculcate in students a commitment to social or political justice. ${ }^{11}$ But doctrinal courses teach students that the law matters, that a person can have better or worse interpretations of the law, that she can get it wrong, and that getting it

A different but sympathetic perspective, one that grounds its arguments for reform in academic legal study, is offered by John D Whyte. See John D Whyte, "Finding Reality in Legal Education” (2013) 76:1 Sask L Rev 95.

In theoretical accounts based on the moral agency of the lawyer, like David Luban's, serious moral obligation will prevail over legal requirements in determining a lawyer's course of conduct. In those accounts, however, the justifiable violation of law follows from that moral obligation, not the client's interests. See David Luban, Legal Ethics and Human Dignity (Cambridge: Cambridge University Press, 2007) [Luban, Human Dignity]. Further, and as discussed below, even in accounts based in moral philosophy, law plays a central role in setting the content of the lawyer's duties and obligations. See text accompanying note 47.

$9 \quad$ Deborah L Rhode, "Legal Education: Rethinking the Problem, Reimagining the Reforms” (2013) 40:2 Pepp L Rev 437 at 450.

$10 \quad$ Yates, supra note 2 at 240.

11 See e.g. Charity Scott, "Collaborating with the Real World: Opportunities for Developing Skills and Values in Law Teaching” (2012) 9:2 Indiana Health L Rev 411 (suggesting that law students “need to learn more than just the law" at 412). Law schools need to help students develop "[v]alues, ethics, and other professional qualities and traits" which include "[s]triving to promote justice, fairness, and morality" (ibid at 417). 
wrong constitutes failure. ${ }^{12}$ Through emphasizing and reiterating the centrality of law in legal training, doctrinal courses teach students that the law fundamentally defines and constrains what lawyers may accomplish on behalf of their clients. As a result, doctrinal law teaching helps to encourage and support ethical legal practice.

Part II of this article situates this argument in the context of recent critiques of legal education. Part III identifies the significance of the process and substance of law in determining the nature and scope of the lawyer's role. Part IV assesses what this perspective on the importance of doctrinal law means for reforms to legal education.

Legal education could be better. It could be more innovative and more creative, and could offer more to students during the three years they spend in law school. It could provide students with more skills to translate their knowledge of, and commitment to, the law into ethical conduct in practice. But law schools should not be ashamed to encourage their students to "think like a lawyer," when thinking like a lawyer involves thinking seriously about the demands and requirements of law. Law schools could do more, but they ought not to do less in reinforcing the accomplishment of that ability in their students.

\section{Too Much Law: The Problem With Legal Education}

In the last three years over 40 articles have been published in American law reviews discussing issues with legal education and how it could be improved. Despite that remarkable scholarly output, and the varying recommendations about possible reforms proposed by different scholars, several common themes emerge. Most obviously, the critics note the deficiencies in law schools' dominant emphasis on doctrinal law and the cognitive skills associated with legal analysis. James Moliterno, for example, suggests that "[t]eaching one skill — legal analysis — as was done from the 1880s until the 1980s, is no longer enough."13 Brent Newton suggests that "law schools focus disproportionately on developing cognitive competencies"14 and Neil Dilloff suggests that law schools need to address "the perceived gap between what currently is being taught in the nation's law schools and what various practicing members of the legal profession believe needs to be taught."15 Deborah Rhode argues that law schools' traditional "combination of lecture and Socratic dialogue that focuses on doctrinal analysis" does not reflect the diversity of students in law school classrooms nor achieve the pedagogical goals that a law school ought to have. ${ }^{16}$

In identifying the deficiencies of this approach, critics tend to focus on one of two central weaknesses: that exclusive focus on analysis of legal doctrines does not teach law students

12 It may be possible to further assert that doctrinal teaching directs students towards trying to identify right answers in their interpretation of law. That further assertion depends, however, on having a complex attitude towards "right-ness" in law, one that takes into account that law is an argumentative discipline, and that a right answer is one that falls within the bounds of legal argument, rather than representing a specific position or outcome. See generally Neil MacCormick, Rhetoric and the Rule of Law: A Theory of Legal Reasoning (Oxford: Oxford University Press, 2005).

13 Moliterno, supra note 4 at 429.

14 Brent E Newton, "The Ninety-five Theses: Systemic Reforms of American Legal Education and Licensure” (2012) 64:1 SCL Rev 55 at 83.

$15 \quad$ Neil J Dilloff, "Law School Training: Bridging the Gap Between Legal Education and the Practice of Law” (2013) 24:2 Stan L \& Pol’y Rev 425 at 426 [emphasis in original].

$16 \quad$ Rhode, supra note 9 at 448. 
the other skills and competencies necessary for legal practice - particularly the sort of complex and varied legal practice now emerging - or that it does not help them develop the attributes and competencies necessary for ethical professional practice.

On the practice side critics suggest that in the traditional legal education model students learn cognitive skills of legal analysis but they do not learn other essential skills for legal practice such as teamwork, problem-solving, effective oral and written communication, practical judgment, time management, practice management, project management, organizational behaviour, business skills, leadership, specialized knowledge, or how to respond to the changing legal services market. ${ }^{17}$ Most importantly, students do not learn how to speak with clients, how to identify or address their needs, or how to identify creative and innovative solutions on their behalf. ${ }^{18}$ Gillian Hadfield put it this way: "These students know a phenomenal amount of information; they just do not have much of a sense of what to do with their knowledge or how to add value to a client's problem."19

On the ethics side the critics suggest that emphasis on doctrinal learning obscures the moral dimensions of a lawyer's work and does not permit students to develop their professional identity, which "encompasses ethical decision-making, professionalism, and social responsibility to ensure access to justice."20 Simply instructing students in the law governing lawyers may be "counter-productive to the formation of the capacity for ethical sensitivity required for professional judgment." ${ }^{21}$ Law students do not learn what they ought to, namely, "a moral core of service to and responsibility for others."22

In developing these common themes, the legal education reform literature makes three significant assumptions about doctrinal teaching. First, it assumes that when students learn doctrinal law they learn only that specific sort of substantive knowledge (that is, legal

$17 \quad$ Moliterno, supra note 4 at 430; Newton, supra note 14 at 83-86; Dilloff, supra note 15 at 430-31; Henderson, supra note 5 at 505; Morgan, supra note 4 at 817; Robert J Rhee, "On Legal Education and Reform: One View Formed from Diverse Perspective” (2011) 70:2 Md L Rev 310 at 329, 332, 337; R Michael Cassidy, "Beyond Practical Skills: Nine Steps for Improving Legal Education Now” (2012) 53:4 BCL Rev 1515 at 1518-25; Brook K Baker, "Practice-Based Learning: Emphasizing Practice and Offering Critical Perspectives on the Dangers of “Co-Op’tation” (2011-2012) 56:2 NYL Sch L Rev 619; Eugene Clark, "Looking Forward: Challenges Facing Legal Education in the 21st Century” (2010) 3:2 Phoenix Law Review 461 at 469; Susan Swaim Daicoff, “Expanding the Lawyer's Toolkit of Skills and Compentencies: Synthesizing Leadership, Professionalism, Emotional Intelligence, Conflict Resolution, and Comprehensive Law” (2012) 52:3 Santa Clara L Rev 795; Steven I Friedland, “Trumpeting Change: Replacing Tradition with Engaged Legal Education” (2011) 3:1 Elon L Rev 93 at 95, 107-15.

18 Dilloff, ibid at 442; Clark D Cunningham, "Should American Law Schools Continue to Graduate Lawyers Whom Clients Consider Worthless?” (2011) 70:2 Md L Rev 499; Scott, supra note 11 at 412; Gillian K Hadfield, "Equipping the Garage Guys in Law” (2011) 70:2 Md L Rev 484 (“[w]here, I have often wondered, are our own 'garage guys' - the ones who challenge the orthodoxy and invent the new world in law? We are simply not giving law students the tools they need. Instead, we are increasingly giving them tools that their prospective clients do not want” at 487).

Hadfield, ibid at 490.

Miriam R Albert \& Jennifer A Gundlach, “Bridging the Gap: How Introducing Ethical Skills Exercises Will Enrich Learning in First-Year Courses” (2012) 5:1 Drexel L Rev 165 at 184. See also The Carnegie Report, supra note 2 at 30-31; Rhode, supra note 9 at 450; Yates, supra note 2 at 237; Cassidy, supra note 17 at 1524-25; Alexander, supra note 6; Clark D Cunningham \& Charlotte Alexander, "Developing professional judgment: law school innovations in response to the Carnegie Foundation's critique of American legal education” in Michael Robertson et al, eds, The Ethics Project in Legal Education (Abingdon, UK: Routledge, 2011) 79; Denise Platfoot Lacey, "Embedding Professionalism into Legal Education” (2012) 18 Journal of Law, Business \& Ethics 41 at 46-47.

21 Cunningham \& Alexander, ibid at 86.

22 Neil Hamilton \& Verna Monson, "Legal Education's Ethical Challenge: Empirical Research on How Most Effectively to Foster Each Student's Professional Formation (Professionalism)” (2011) 9:2 University of St Thomas Law Journal 325 at 328. 
doctrine) and the analytical skills that go along with applying it. Doctrinal learning does not result in the accomplishment of practical skills and it does not develop ethical practitioners. Rather, doctrinal instruction teaches "one skill," and the skill it teaches is more suitable for "law professors," than for the lawyers most students will become. ${ }^{23}$

Second, the literature tends to assume that learning how to be responsive to client needs, and to innovate on their behalf, exists in tension with, or in contrast to, emphasis on doctrinal learning - at best doctrinal learning is information that students know but have no capacity to employ on a client's behalf. ${ }^{24}$ It does not contribute to students' understanding of how they ought to relate to their clients or fulfill their needs.

Finally, and relatedly, it assumes that the relevant ethical knowledge for lawyers and law students exists apart from the law, linking to morality, justice, fairness or humanity writ large, rather than to the norms and obligations of legality. For law students to become ethical practitioners requires that they learn something more, or other, than what the law provides.

In making each of these assumptions the literature does not allow for the significant relationship between the substance and process of law, and the social role that lawyers play. In particular, it does not allow for the possibility that learning doctrinal law achieves more than cognitive skills, and in fact grounds and defines the work that lawyers do for their clients, forming the true heart of the lawyer's ethical obligations and professional identity. When the relationship between the law and the lawyer's role is properly accounted for, the place of doctrinal law in legal education appears quite different, and more significant, than is generally acknowledged by its critics. ${ }^{25}$ The following section sets out the basis for asserting the irreducible significance of law in determining the duties and obligations of lawyers in fulfilling their social role.

\section{LAW AND THE LAWYER}

\section{A. INTRODUCTION}

The assertion that the law has irreducible significance in understanding the lawyer's ethical obligations and social role is grounded in three observations about the intersection of the law and the work of the lawyer. First, the specific duties and obligations imposed on lawyers in practice are largely parasitical on the content and process of the law as a whole. The process of making ethical decisions is importantly distinct from the process of legal reasoning and analysis, but the content of the ethical decisions that lawyers are required to make follows from legal analysis and reasoning. That is, what the law requires determines what the lawyer must do in representing a client. Second, identification of the normative foundations of the lawyer's role reveals the centrality of legality to that role, even when one takes into account the significantly divergent normative accounts offered for the lawyer's

See Moliterno, supra note 4 at 426, 429.

See Hadfield, supra note 18 at 490.

Some critics give more prominence to doctrinal law, or at least are more conservative in their recommendations about how legal education should be changed. In my view those proposed reforms are the sort that ought to be adopted — the ones that seek to expand and improve legal education, while not abandoning its emphasis on the law. See Rhee, supra note 17; Morgan supra note 4. 
role. $^{26}$ Third, the most serious ethical scandals involving lawyers have arisen not from lawyers failing to maintain a commitment to morality or justice, but rather from lawyers failing to identify and comply with the obligations of substantive law. This section sets out the basis for each of these observations.

\section{B. Defining Lawyer’s Professional Duties in Practice}

In providing legal services to clients, lawyers undertake various obligations in relation to, inter alia, advising, advocating, negotiating, maintaining confidences, and avoiding conflicts of interest. Fulfilling those obligations requires lawyers to have a set of skills and competencies distinct from ordinary legal analysis and reasoning; what will allow a lawyer to determine the content of and apply, for example, the law of offer and acceptance in writing a contract for a client, is not the same as what will allow a lawyer to determine the content of and apply the law on conflicts of interest in deciding whether to accept a retainer. The reason for this is that the latter decision is specifically about the lawyer's own conduct - it is about what the lawyer ought to do, or is required to do — rather than being an impersonal decision about what the law says in relation to a third party. ${ }^{27}$ It is for this reason that concepts of moral reasoning and decision-making are useful in thinking about how lawyers fulfill their professional obligations; the cognitive and emotional aspects of moral decisionmaking apply to decisions by lawyers about what they ought to do when representing clients. Whether discharging professional or personal obligations to do the right thing, lawyers have to be aware of the role of intuitions and cognitive biases, and of situational pressures, in influencing their ability to implement the correct decision.

That said, however, the content of lawyer's ethical decisions — what distinguishes a good and justifiable decision (the right thing) about how to represent a client from a bad and unjustifiable decision (the wrong thing) — follows not from the norms and obligations of morality, but rather from the norms and obligations of legality. Take the example noted above, about offer and acceptance in contracts versus identifying a possible conflict of interest. While the reasoning process in each decision is distinct - because in the latter case the lawyer is assessing her own conduct, while in the former case she is assessing a third party's situation - the source for determining the answer to the question is essentially identical. The law on offer and acceptance arises from case law, with some relevant statutory principles to be applied in specific settings, such as consumer transactions. The law on conflicts of interest arises from case law, with some additional guidance through the rules promulgated by the statutorily created regulatory bodies that govern the legal profession. ${ }^{28}$ A decision on whether to act in a potential conflict situation is characterized as an ethical one, but the answer to that question arises wholly from law, not from morality or ethics apart from law.

26 On the variation between different normative accounts see Alice Woolley, "The Problem of Disagreement in Legal Ethics Theory” (2013) 26:1 Can JL \& Jur 181.

This distinction is explained further in Alice Woolley \& Sara L Bagg, "Ethics Teaching in Law School” (2007) 1 CLEAR 85 at 91-95.

See e.g. Canadian National Railway Co v McKercher LLP, 2013 SCC 39, [2013] 2 SCR 649 [McKercher]; Strother v 3464920 Canada Inc, 2007 SCC 24, [2007] 2 SCR 177; $R v$ Neil, 2002 SCC 70, [2013] 3 SCR 631 [Neil]; MacDonald Estate v Martin, [1990] 3 SCR 1235; Federation of Law Societies, Model Code of Professional Conduct (Ottawa: Federation of Law Societies, 2012) r 3.4; Law Society of Alberta, Code of Conduct (Calgary: Law Society of Alberta, 2013) r 2.04. 
This is the case in almost every area where lawyers will make decisions about how to act in the discharge of their professional roles. In general, and as emphasized in repeated Supreme Court judgments, the lawyer's obligations arise in significant part from the law on fiduciary obligations; how a lawyer acts in relation to her client is defined by the lawyer's status as a fiduciary to that client. ${ }^{29}$ More specifically, the lawyer's duties to maintain a client's confidences arise from codes of conduct but are also informed by the law of privilege and the common law duty of confidentiality. ${ }^{30}$ The lawyer's duties in examining a witness, either in direct examination or cross-examination, turn on the law of evidence, and what courts do and do not permit in the presentation of testimony to the court. ${ }^{31}$ Thus, for example, the contentious issue in the American legal ethics literature of the ethical duties of a criminal defence lawyer when cross-examining a witness in a rape case on her sexual history is at least partially resolved in Canada through the enactment of rape-shield legislation. ${ }^{32}$ Similarly, when the Supreme Court of Canada recently held that a lawyer's advice to a witness provides no guarantee of the reliability of a witness's testimony, the Supreme Court made a legal determination about the duties of a lawyer when deciding whether to present the testimony of a witness the lawyer suspects will be untruthful. ${ }^{33}$ The fees that a lawyer can charge to clients are affected by the rules of court and the taxation power, and the ability of taxation officers to adjust a lawyer's account if that account is not just or reasonable. ${ }^{34}$ The lawyer's obligations of honesty in negotiations are affected not only by ethical rules imposing honesty, but also by the law of misrepresentation in contracts, and the impact a misrepresentation may have on the contract's ultimate enforceability, and by the law of fraud. In a classic legal ethics hypothetical posited by Allan Hutchinson, in which students are asked whether they can accept a settlement on behalf of a client who the lawyer (and the other side) thought was HIV positive but who the lawyer now knows is not HIV positive (while the other side remains misinformed), the answer arises from the law of fraud, not from morality or ethics apart from law. That is, the lawyer cannot accept the settlement on the client's behalf because to do so would be to participate in the commission of fraud, regardless of any moral or ethical concerns with doing so. ${ }^{35}$

Any number of further examples could be given in relation to the particular duties of lawyers. The essential point, though — and this is highlighted by the Hutchinson hypothetical - is that when lawyers act for clients the law determines the nature and extent of that representation. A lawyer cannot commit fraud for a client. A lawyer cannot advise a client to violate or ignore the law. The law is more than a gunman writ large ${ }^{36}$ and lawyers have only law, not guns. This point will be developed further in relation to the normative foundations of the lawyer's role, but even when describing the regulatory and legal

See e.g. McKercher, ibid; Neil, ibid.

See Alice Woolley, Understanding Lawyers' Ethics in Canada: Inspired by Monroe Freedman and Abbe Smith's Understanding Lawyers' Ethics (Markham: LexisNexis, 2011) at 107 [Woolley, Understanding Lawyers' Ethics].

See e.g. $R v$ Lyttle, 2004 SCC 5, [2004] 1 SCR 193; $R v R$ (AJ) (1994), 20 OR (3d) 405 (CA).

Woolley, Understanding Lawyers' Ethics, supra note 30 at 212.

$R v$ Youvarajah, 2013 SCC 41, [2013] 2 SCR 720 at para 61.

Alice Woolley, "Time for Change: Unethical Hourly Billing in the Canadian Profession and What Should Be Done About It” (2004) 83:3 Can Bar Rev 860 at 869.

See Allan C Hutchinson, Legal Ethics and Professional Responsibility, 2d ed (Toronto: Irwin Law, 2006) at $1-2$.

See HLA Hart, The Concept of Law, 3d ed (Oxford: Oxford University Press, 1961) at 80. 
constraints placed on lawyers in practice, it cannot be overemphasized that all a lawyer can ever offer to a client is that which the law provides.

Lawyers do have some obligations not determined by law. The most obvious example is client selection, where apart from certain legal constraints (such as avoiding conflicts of interest) lawyers may exercise their discretion (ethical or otherwise) in deciding which clients to represent. ${ }^{37} \mathrm{~A}$ lawyer may also experience circumstances where his moral conscience conflicts with what the law permits or requires of him in discharging his obligations. That is a distinct sort of ethical dilemma that the content of law cannot resolve; in those circumstances the best that can be said is that the lawyer faces a conflict between her professional and moral duty. ${ }^{38}$ Nonetheless, the starting point in any discussion of the lawyer's duties and obligations in practice is the substance and process of law.

When I teach a course on lawyers' ethics, or write a book about lawyers' ethics, the subject matter is properly described as "ethics” for two reasons. First, the decisions being made are ones about the lawyer's own conduct, and follow decision-making processes closely related to what we would think of as ethical or moral decisions in ordinary life. Second, there are some decisions that a lawyer must make that are not determined by law, or not wholly satisfactorily answered by law. Nonetheless, that the subject matter is called legal ethics, or lawyers' ethics, should not obscure the pivotal place of the law in determining the content of legal ethics in practice. However one may think of these questions theoretically (and as will be apparent from the next section, the theoretical position is actually much the same), for practicing lawyers the ethical questions are in substance legal ones.

\section{THE NORMATIVE FOUNDATIONS OF THE LAWYER'S ROLE}

That the law determines the content of lawyers' duties and obligations in practice is unsurprising when those duties and obligations are considered through theoretical accounts of the lawyer's role. Explaining how this is the case is somewhat complicated by the significant variation between different theoretical accounts. Theorists explain the lawyer's duties and obligations variously depending on whether their account is informed by conceptions of law arising from political philosophy, or from the tenets of moral philosophy. In the three perspectives that make up the majority of legal ethics scholarship, theorists rely on, respectively, positivist accounts of the function of law, Dworkinian accounts of the function of law, or the moral agency of the individual lawyer. ${ }^{39}$ In each of those theoretical perspectives, the manner in which the law informs the lawyer's duties and obligations varies. That the content of law does so, however, is nonetheless clear.

Woolley, Understanding Lawyers' Ethics, supra note 30 at 46-52.

Competing normative responses to how the lawyer ought to resolve it are discussed in the following section.

Other notable ethical accounts include those that arise from a virtue ethics approach. See Andrew A Ayers, “What if Legal Ethics Can’t be Reduced to a Maxim?” (2013) 26:1 Geo J Legal Ethics 1. See also Allan C Hutchinson, “Calgary and Everything After: A Postmodern Re-vision of Lawyering” (1995)

33:4 Alta L Rev 768 (demonstrating a post-modernist perspective at 781-82); Trevor CW Farrow

"Sustainable Professionalism” (2008) 46:1 Osgoode Hall LJ 51. 
This is most straightforwardly the case for the positivists. Following from the seminal article by Charles Fried, “The Lawyer as Friend: The Moral Foundations of the LawyerClient Relation," the positivists locate the content of the lawyer's duties in the function of law as a form of social settlement. ${ }^{40}$ Through enacting substantive rules through democratic processes the law contains our legitimate compromises about difficult moral questions, and provides a means to settle disputes that may arise about the right way to act. It provides a way for us to live peacefully despite our disagreements about how to live. The role of the lawyer is to allow each of us to access that social settlement, to pursue freely those activities that the law does not prohibit and to access the entitlements that the law provides. It allows each of us to govern our affairs in accordance with our own beliefs and desires and the legitimate terms established for our collective interactions. As a consequence of these central principles - that individuals have different conceptions of the right way to live, and that the law provides a way for individuals nonetheless to live together without violence - the two central norms that define the lawyer's role are that she provide zealous advocacy for clients, and that she do so within the bounds of legality. ${ }^{41}$ A lawyer can only ever do for a client that which the law permits, and the lawyer must approach the law seriously and in good faith in identifying what that is. When a lawyer takes a moral position inconsistent with the law's requirements she usurps the function of law and privileges her personal conception of the good over her fellow citizens. When she follows her client's wishes without serious and good faith attention to the demands of law, she privileges her client's interests similarly. In the positivist conception, serious and faithful attention to the process and substance of law is the central professional virtue of the lawyer.

The Dworkinian account places similar emphasis on the role of law in defining the lawyer's obligations; the difference is only that the Dworkinian model would, following Dworkin's jurisprudence, have the lawyer approach the law in light of its inherent morality and instantiation of justice. As expressed by William Simon, the lawyer ought to pursue "legal merit"; that is, he ought to take those "actions that, considering the relevant circumstances of the particular case, seem likely to promote justice." ${ }^{22}$ While Dworkinians like Simon interpret and understand law somewhat differently from the positivists, they similarly understand the role of the lawyer through law, and define the lawyer's obligations in terms of what the law requires. Neither the client's wishes, nor morality apart from law, ought to determine the lawyer's actions in discharging her professional obligations. ${ }^{43}$

$40 \quad$ See generally Charles Fried, "The Lawyer as Friend: The Moral Foundations of the Lawyer-Client Relation” (1976) 85:8 Yale LJ 1060; Tim Dare, The Counsel of Rogues? A Defence of the Standard Conception of the Lawyer's Role (Farnham, UK: Ashgate, 2009); W Bradley Wendel, Lawyers and Fidelity to Law (Princeton: Princeton University Press, 2010); Woolley, Understanding Lawyers' Ethics, supra note 30 at 40-43. One of the arguments in Understanding Lawyers' Ethics is that this account of the lawyer's role is also reflected in Canadian substantive law about the function of law and the role of lawyers in the legal system.

41 An additional principle necessary for recognizing the lawyer's role is that the law is too complicated for individuals to access without the assistance of a lawyer. If the law were straightforward and accessible the social settlement could theoretically be achieved without the assistance of lawyers - each citizen could simply access what the law provides.

42 William H Simon, The Practice of Justice: A Theory of Lawyers'Ethics (Cambridge: Harvard University Press, 1998) at 138. See also William H Simon, "Ethical Discretion in Lawyering” (1988) 101:6 Harv L Rev 1083.

43 It should be noted as well that one could adopt a variety of jurisprudential perspectives apart from a straightforward positivism or a rigorous Dworkinianism. Jeremy Waldron's work on the rule of law indicates some of the jurisprudential complexities that can be incorporated in understanding what it means for a society (and lawyers) to respect the rule of law. The point remains, though, that as a lawyer in such a society one's fundamental obligations are to allow the citizenry to access the law while 
The emphasis on law causes disquiet in some, and in particular those who note lawyers' moral agency. On what basis, they ask, does professional duty usurp the obligations of any agent choosing between morally justifiable and morally unjustifiable acts? Thus, in another foundational work Richard Wasserstrom observed the centrality of law in defining the lawyer's obligations, but suggested that this centrality created a fundamental moral problem for lawyers. ${ }^{44}$ Specifically, the disjunct between morality and law means that lawyers properly discharging their professional obligations may end up violating moral rules. Lawyers, Wasserstrom suggested, face a peculiar moral catch-22: they must either embrace the immoral ends for which they advocate or embrace "hypocrisy and insincerity" in pursuing those moral ends, with either choice effectively compromising their moral integrity. ${ }^{45}$ From a similar perspective moral philosophers Gerald Postema and David Luban argue that lawyers retain full moral responsibility for the actions they take, regardless of whether those actions are dictated by their professional role. ${ }^{46}$ For Luban, while lawyers may act with the "presumption in favour of professional obligation" they must ultimately assess their decisions against the requirements of morality: "[W]hen professional and serious moral obligation conflict, moral obligation takes precedence."

These normative assessments of the lawyer's role from the perspective of the lawyer's moral agency appear to contradict not just the positivists and Simon, ${ }^{48}$ but also the general position that the law has precedence in identifying lawyers' ethical duties and obligations. If morality always governs, then ought not lawyers to be primarily concerned with the content of morality in assessing their actions? Surprisingly, perhaps, that statement does not follow from the theories that note the moral agency of lawyers; indeed, emphasis on moral agency is far less contradictory to the significance of law for identifying the lawyer's obligations than first appears.

Luban, for example, clearly locates the professional obligation of lawyers in the law. This is particularly evident in his essays on legal advising, in which he argues that the "regulative ideal" for lawyer advising ought to be providing "his professional opinion as to what the law actually requires." ${ }^{49}$ Luban further develops this point in his critique of the "torture lawyers of Washington," the lawyers at the Office of the Legal Counsel who provided advice to the George W. Bush administration in favour of the legality of that administration's "enhanced interrogation" methods (that is, torture). The wrongfulness of the torture lawyers' conduct does not arise only from their collusion in one of "the most fundamental affronts to human

respecting the law's legitimacy and authority. See generally Jeremy Waldron, "The Concept and the Rule of Law" (2008) 43:1 Ga L Rev 1.

Ibid at 14

$46 \quad$ See e.g. Gerald J Postema “Moral Responsibility in Professional Ethics” (1980) 55:1 NYUL Rev 63; Gerald J Postema, "Self-Image, Integrity, and Professional Responsibility" in David Luban, ed, The Good Lawyer: Lawyers' Roles and Lawyers’ Ethics (Totowa, NJ: Rowman \& Allanheld, 1983) 286; David Luban, Lawyers and Justice: An Ethical Study (Princeton: Princeton University Press, 1988).

$47 \quad$ Luban, Human Dignity, supra note 8 at 63.

48 The contradiction with Simon is subtle, since Simon's position on the law - that it ought to be interpreted in accordance with justice - potentially reduces the circumstances in which law and morality conflict to nil. On the other hand, the moral obligations of justice may conflict with other moral norms. It seems likely that placing morality as a whole in precedence to law will from time to time result in different act prescriptions than when one follows the obligations of law in light of the law's moral function. 
dignity." ${ }^{50}$ It also arises from the sheer badness of the legal advice they offered. Luban acknowledges that the law does not yield clear and determinate answers simply through reading it (although he also suggests that "[l]aw does its job properly when it is all surface and no depth and what you see is exactly what you get"51). But the indeterminacy of the law is of a "special and limited sort" and does not prevent the identification of frivolous, wrong, or improper legal arguments. The law's interpretive community — lawyers, judges, and participants such as administrative decision-makers - creates norms of interpretation that permit distinctions between the frivolous and the plausible. For Luban, the improper conduct of the torture lawyers arose from their failure to stay on the right side of that line, and their manipulation of their opinions to reach the result desired by their client, whatever its actual legality. ${ }^{52}$ To write opinions as they did, with no real commitment to identifying a plausible and defensible legal answer, was to "betray their craft." 53

Thus, while at the point of conflict with morality these accounts of the normative foundations of the lawyer's role diminish the authority of law, they do not do so generally. The law defines the lawyer's professional obligations, and presumptively determines what the lawyer ought to do. In a case of conflict with morality the lawyer has a further dilemma, but even that dilemma can only be assessed after consideration of the obligations imposed by law. And to the extent a lawyer follows morality in precedence to law, the lawyer will have violated her professional duties; she may do so rightly, and even necessarily, but that is the nature of the choice that she makes. ${ }^{54}$

It should also be noted that while beloved of ethics writers everywhere, the circumstances in which a lawyer will face a genuine conflict between professional duty and serious moral obligation are almost certainly exceptional. In many cases - such as the prohibition of torture - law and morality align. And in other cases, for lawyers working in areas less likely to raise serious moral concerns, the norms of morality may simply not come into play very often. The divergence between the claims of law and morality is observable, but ought also not be treated as the standard case.

The significance of this point can be appreciated when the nature of misconduct by actual lawyers is considered. As discussed in the next sub-section, when lawyers act badly their behaviour has normally involved violations of the law, as opposed to compliance with law and violation of morality.

\section{Ibid at 163 .}

Ibid at 194.

See ibid at 197.

Ibid at 205.

It should be noted that positivists allow for the possibility that a lawyer will choose to follow the dictates of morality in precedence to professional obligation. Thus, for example, Wendel notes in discussing the famous case of Spaulding $v$ Zimmerman, in which a lawyer's professional duty of confidentiality required that information not be disclosed, but the failure to disclose the information could have resulted in a young man's death, that many lawyers (including himself) would be prepared to violate professional obligation in that circumstance. The point of the positivists is only that the professional obligation remains - the lawyer simply has to choose whether she will violate that duty or violate the obligations of morality; there is no path forward which does not involve a violation of some kind or another. See W Bradley Wendel, "Civil Obedience” (2004) 104:2 Colum L Rev 363 at 404. See also Spaulding v Zimmerman, 116 NW (2d) 704 (Minn 1962). 


\section{LAWYERS ACTING BADLY}

What does misconduct by lawyers look like? Different sources could be relied on to answer this question, but one approach is to consider some of the more notorious lawyer misconduct scandals that have occurred in Canada and the United States in recent years, such as the torture lawyers, Enron, the Murray/Bernardo videotapes, and the Wirick mortgage fraud in British Columbia. ${ }^{55}$ The advantage of these cases is that, in contrast to lawyer discipline or court cases, they do not necessarily require a finding of legal wrongdoing by the lawyers. They could, at least conceivably, have involved lawyers acting immorally but not unlawfully, whereas lawyers subject to formal legal sanction will always be found to have acted unlawfully. If ethics and morality matter in addition to law, it is in these sorts of cases that those failings will be apparent.

In each of these famous cases the failure of the lawyers can be characterized in moral terms, but also — and significantly — involved a failure to comply with the obligations of law. The torture lawyers, as noted above, drafted opinions that "barely [go] through the motions of standard legal argument." 56 In the case of Enron, the substantive failure of the lawyers was assisting Enron to evade the legal obligations governing financial reporting. As documented by the examiner appointed by the bankruptcy court to review Enron's affairs, including potential causes of action against Enron's attorneys, lawyers assisted Enron to use legal forms for transaction that were sufficiently divergent from the economic substance of the transaction as to make the legal form of suspect validity. ${ }^{57}$ Through the manipulation of those legal forms they hid the reality of economic transactions appearing on Enron's financial statements, thereby helping Enron's management to present a financial picture that did not represent reality. ${ }^{58}$ When Murray did not reveal the videotapes of the crimes committed by his client, Paul Bernardo, he committed the act of obstruction of justice, a criminal offence, without any legal justification for doing so (albeit without the requisite mens rea, which is why he was acquitted).$^{59}$ Martin Wirick facilitated his client's \$50 million fraud by failing to comply with his legal obligations with respect to his trust accounts and legal undertakings he provided to other counsel. ${ }^{60}$

In each of these cases the lawyer's wrongdoing may have arisen because of deficits in their process of ethical decision-making rather than legal ignorance. For example, as Mitt Regan has documented, the Enron lawyers did not so much fail to understand what the law required as that they failed to identify the proper legal significance of the things that their client was doing. ${ }^{61}$ That failure arose because of the sorts of cognitive biases and weaknesses that tend to make it harder for us to make the right choices about our own conduct (in other

55 For an account of the key legal ethics stories in Canada in recent years, see Adam M Dodek, "Canadian Legal Ethics: Ready for the Twenty-First Century at Last” (2008) 46:1 Osgoode Hall LJ 1 at 9-15.

Luban, Human Dignity supra note 8 at 198.

See Milton C Regan, Jr, “Teaching Enron” (2005) 74:3 Fordham L Rev 1139.

Vinson \& Elkins, one of the law firms criticized by the examiner, eventually settled with Enron for \$30 million, although did not admit wrongdoing. John C Roper, "Vinson \& Elkins settles with Enron for \$30 million,” Houston Chronicle (2 June 2006), online: Houston Chronicle <http://www.chron.com/ business/enron/article/Vinson-Elkins-settles-with-Enron-for-30-million-1895559.php>.

$R v$ Murray (2000), 48 OR (3d) 544 (Sup Ct J).

Law Society of British Columbia v Wirick, [2002] LSBC 32.

Regan, supra note 57. 
words, ethical choices). Nonetheless, the content of those lawyers' mistakes arose from their legal inadequacy, not their moral inadequacy.

\section{CURRICULUM REFORM AND THE ETHICAL LAWYER}

This foundational relationship between the law and the content of lawyers' duties and obligations calls into question the assumptions made by the legal education reform literature. It suggests that placing doctrinal law at the centre of legal education does more than privilege cognitive skills and legal analysis over other skills that lawyers may need to practice law successfully and effectively. Emphasis on teaching the substance and process of law also properly communicates to students that plausibly and defensibly applying law is what lawyers do, and is what they ought to do when discharging their professional responsibilities. Further, it suggests that while advising clients requires skills beyond cognitive legal analysis, client advising ought not to be viewed as contrary to or in tension with the law. Rather, as Luban notes, the heart of client advising involves identifying the intersection between your client's goals and aims and the law. ${ }^{62}$ Finally, and most importantly, it suggests that the creation of "professional identity" or ethics in practitioners not only does not need to focus on developing a commitment to morality, justice, and fairness per se, but ought to make consideration of those abstract moral concerns secondary to the duties and obligations that arise in law. It may be tempting to assert that the ethics of lawyers are the ethics of morality; doing so allows the profession to claim a less ambiguous social place than it has traditionally occupied. There is, however, no descriptive or normative basis for that assertion; the ethics of lawyers arise, in substance, from the process and substance of law.

Obviously simply teaching doctrinal law will not, in and of itself, provide students with the skills sufficient to ensure that they appreciate the importance of ensuring their legal practice complies with the requirements of legality, or that they have the skills to do so. The various examples of ordinary and even brilliant lawyers who have failed to stay within the bounds of the law demonstrate that point. As Luban observes in his discussion of advising, the economic and other pressures of legal practice may push some lawyers to "spin the law to support whatever the client wishes to do." ${ }^{\text {"3 }}$ Knowing what the law requires in the abstract is a different sort of skill then knowing what the law requires, and how to communicate that knowledge, when the answer is one that the client does not want to hear.

Moreover, as noted earlier, determining how the law affects a person's own actions, what it does and does not permit a person to do, requires skills of ethical decision-making that are not coterminus with legal reasoning and analysis. The content of lawyers' professional obligations arises from the law, but recognizing when an issue has arisen that ought to change the lawyer's behaviour, and what the content of law means for how the lawyer should act, has cognitive and emotional features that are distinct from legal reasoning and analysis in the abstract where no personal concerns of the lawyer are at stake. Emotional responses, intuitions, and cognitive biases, both good and bad, will inform those decisions in the way 
they inform all of the decisions people make about themselves and what a person ought to do. ${ }^{64}$

In short, then, doctrinal analysis is important, and is more important than the legal education reform literature allows, but it is not exclusively important. This leads to some further specific observations about how law schools should approach and revise their approach to doctrinal teaching. Most importantly, law schools ought to keep teaching legal doctrine and analysis as independent and strong areas of importance within the law school curriculum. It is true that abstract learning of doctrinal law will not teach students how to apply the law in practice, where the pressures to give different answers, or to act inconsistently with the law, may be acute. But the constant reiteration of the importance of law in traditional law school classrooms, of the idea that the law can be understood and applied through recognizable forms of reasoning and argument — may provide intuitions and unconscious cognitive orientations towards the significance of legality. Those intuitions and unconscious orientations may help graduates resist some of the pressures of practice that encourage lawyers to substitute their client's desired result for the result that would obtain simply by reading and assessing the law.

A lawyer who acts with the unconscious assumption that her job is to figure out the law may be less likely to succumb to the pressures to provide answers to clients that the law does not plausibly permit. And a lawyer whose law school experience included a strong emphasis on learning the law may be more likely to make that unconscious assumption. There are many reasons for the fact that it is senior lawyers who end up in disciplinary trouble with law societies not junior ones - they are the lawyers with the most responsibility for files and for managing practices, and particularly trust accounts - but one small part of that equation may be that they are the lawyers farthest removed from the way law is thought about in law school.

This argument relies on a degree of speculation. The effects of learning doctrinal law on a lawyer's attitude to the authority and legitimacy of law have not been empirically demonstrated. At the same time, however, it seems plausible and consistent with observation of law students to think that the experience of law school, and in particular the first year, results in students internalizing the normative significance of legality - that the law matters. For that reason, instruction in doctrinal law ought to be emphasized for more than its capacity to develop students' cognitive skills of legal reasoning and analysis; it ought also to be emphasized to help ensure that law school graduates understand the importance and significance of law for fulfilling their obligations.

These observations lend support to those proposed reforms of legal education that build on and maintain the strengths of law schools in teaching doctrinal law. Thus, for example, in a 2012 article "The Changing Face of Legal Education: Its Impact on What it Means to Be a Lawyer," Thomas Morgan suggests that law schools develop a "Core-Plus-More” approach to curricular reform, in which law students learn the core concepts of thinking like a lawyer, understanding fundamental questions that arise when working in a legal system, 
and practical skills. ${ }^{65}$ The core requires that students learn careful reading, the skills of inductive reasoning, the ability to place legal issues in their broader policy context and the ability to distinguish legally salient facts. ${ }^{66}$ It requires ensuring that students gain clear understanding of the functioning and substance of the legal system. ${ }^{67}$ Morgan acknowledges that this approach is "more theoretical than the MacCrate or the Carnegie reports" recommended but, for the reasons noted here, his approach would ensure that students were given an educational experience that affirmed the foundational importance of the law to the lawyer's role. ${ }^{68}$ Morgan emphasizes that this education is not in and of itself sufficient students also need to be given skills that will "give clients and other lawyers a reason to seek out that lawyer rather than seeking out someone else" 69 — but his approach allows reform while not abandoning law schools' emphasis on the content of law.

A similar approach is taken by Robert Rhee, who suggests that the first two years of law school remain much as they are, teaching "the difficult skill of 'thinking like a lawyer' within basic, doctrinally important areas of law such as contracts, property, torts, constitutional law, and civil procedure." ${ }^{70}$ He notes that more emphasis could be placed on other skills, and on transactional perspectives rather than purely litigation. ${ }^{71}$ But his overarching point, that " [a] focus on teaching legal analysis should not be seen as conflicting with teaching other valuable professional skills,"72 also implies its opposite - that teaching those other valuable professional skills does not conflict with teaching the law and legal analysis.

The other skills students learn in a reformed law school should include giving students opportunities to apply what they learn in "real life" or quasi-real life scenarios. Developing the intellectual, interpersonal, and emotional skills to allow them to discharge their professional obligations in practice, and despite the pressures that practice can create, does provide an essential corollary to doctrinal learning. As noted, while the content of lawyer's professional obligations focus on law, the application of those skills in the difficult circumstances of practice requires skills of ethical and moral reasoning that, it is fair to acknowledge, law schools have not taught particularly well or effectively. ${ }^{73}$ Experiential learning ought not to replace doctrinal learning, but it can usefully operate in conjunction with that learning to ensure that students learn how to work with the law, and its importance for guiding their practice, while also learning skills that are important for implementing that knowledge outside the confines of the academy.

While this point is consistent with the legal education reform literature, the argument here is also that experiential and practical learning should be closely connected to students' learning about the substantive law and the functioning of the legal system. To put students in environments where the focus is on practice and practicing, without linking those experiences to students' law-focused education, runs the risk that students may consciously

Morgan, supra note 4 at 828-29.

See ibid at 829-30.

See ibid at 831-32.

Ibid at 832.

Ibid at 836.

Rhee, supra note 17 at 327.

Ibid at 327-28.

Ibid at 330 .

See Rhode, supra note 9; David Luban \& Michael Millemann, “Good Judgment: Ethics Teaching in Dark Times” (1995) 9:1 Geo J Legal Ethics 31. 
or subconsciously uncouple legal practice from the substance and process of the law. The emphasis may shift to clients' needs and interests, without the necessary appreciation of the legal boundaries on lawyers' advocacy for those interests. Ensuring the connection between doctrinal learning and practical experiential learning may require only small things, such as ensuring that the lawyers with whom students work are ones the law school is satisfied will connect the student's experience to knowledge of the substance and process of law. Ideally though it would involve more significant connections, in which the experiential and doctrinal learning occur together. An example of this approach is the legal ethics course taught by David Luban and Michael Millemann, in which students' clinical practice was coupled with an ethics seminar in which they worked out ethical problems of practice in a classroom environment. ${ }^{74}$ The professors — Luban and Millemann — were able to bring both practical and abstract expertise to the classroom. Another example is simply incorporating aspects of practice into the classroom - contract drafting into a contract law class, or factum writing in a constitutional class. Innovation and improvement is possible; the only message here is that innovation and improvement ought not to be at the expense of emphasis on the law.

Two further points need to be noted. As anyone involved in legal education knows too well, law schools cannot do everything. Resources are limited — not just financial, but also the energy and enthusiasm of every participant. Students want to learn, but they also want to make a living and pursue other things of interest to them - their hobbies, their relationships, their lives. Structural changes could reallocate law school resources - away from research and towards teaching, for example — but even with those structural changes the fact will remain that no law school can possibly provide a graduate with everything they need to know about being a lawyer, or surviving legal practice. Do I think my law school could have done a better job of preparing me for legal practice? Without a doubt! But do I think they could have truly prepared me for the things I experienced, or the challenges I faced? Not a chance. The point being that legal education reform will always involve tradeoffs, and doing or emphasizing some things more than others. And if law schools have to choose between ensuring their students learn doctrinal law - its content, its significance, and the skills required to analyze and apply it — and something else, law schools ought to choose doctrinal law. Other things are important, but that is the most important.

Finally, this article has said little to nothing about the changing environment for lawyers and law graduates, and the new world that law school graduates may be entering. That is in part because I remain more skeptical than some that we truly understand what those changes are going to be, let alone what their implications will be for the role played by lawyers in the delivery of legal services. Further, and more significantly, if we remain committed to living in a society governed by laws, rather than by raw power, we will need to have some basis for implementing and administering that system, and a variety of functionaries who ensure that the provisions of law can be accessed by the citizenry. Lawyers advocate for clients, but in doing so they serve as legal functionaries, mediating between participants in the legal system, and between participants and that system's rules and requirements. What that functionary role requires - the technological tools through which it is accomplished, the organizational structures within which lawyers work, the intersection between lawyers, clients, and other people who work or participate in the system - may change over time, but the significance 
of law, and the necessity for some mechanism to allow citizens to access the law, will remain. If legal education provides students with the skills necessary to understand, analyze, and apply the law, and a deep commitment to it significance, it will have done something essential for allowing them to discharge their mediating function in the legal system, despite the structural and technical change associated with that role. Certainly law schools ought to do what they can to prepare graduates for changes (once they know what those changes involve and how they will affect the work graduates will be doing) but that preparation need not — and ought not — be at the expense of ensuring sufficient legal knowledge, skills, and commitment.

\section{Conclusion}

Legal education reform literature sometimes seems to offer enthusiastic yet vague exhortations to law schools and the profession to instill ethics and morality in law school graduates, without giving real and serious thought to where, exactly, our professional obligations lie. That law schools ought to teach law students to commit to moral ideals apart from law is a claim in need of an argument, and as the discussion here has suggested, the arguments available seem not to support it. Whatever other moral obligations lawyers may have from time to time, the normal source of their professional obligation is the substance and process of the legal system within which they work. If lawyers did nothing more nor less than provide clients with competent advice and zealous advocacy within the bounds of legality, they would achieve ethical excellence. The law provides the professional identity of the lawyer.

Further, in noting the changes in the way that legal services are or should be delivered, and the things that law schools could do better, commentators tend to lose sight of our raison d'être, namely legality itself. The world may change, but if the rule of law was the thing to be sacrificed, then the need would be for a call to arms, not flexibility and adaptation to evolving circumstances. The changes that are coming, in the organization of the profession, in who provides legal services, in the significance of globalization, are hopefully unlikely to result in that sort of sacrifice; whatever adaptation to change is required, that adaptation can properly remain focused on the role that lawyers play within the legal system that governs their work.

This is not to undermine or diminish the validity of the legal education reformers' overall point. Legal education could be more innovative. It could do a better job at preparing graduates for legal practice. It could in general do more to care deeply about the professional lives its students will ultimately lead — helping them to choose the right sort of practice, and to have the skills necessary to continue to learn to become excellent barristers and solicitors. Legal education should still focus on law, and on the centrality of legality to the social role that lawyers fulfill. But it could do so with a broader and more comprehensive educational agenda in mind. 